Teologia Praktyczna 20(2019)

doi: $10.14746 /$ tp.2019.20.08

ORCID: 0000-0001-7303-463X

BARTŁOMIEJ DOLATA

\title{
Funkcja spowiednika i realizacja sakramentalnej posługi wobec duchowych potrzeb ludzi młodych
}

Prezbiterzy są powołani do tego, aby w duchu Chrystusa, Dobrego Pasterza, nauczać Kościół i prowadzić go do Eucharystii, czyli komunii z Bogiem przez sakrament pokuty (Sobór Watykański II 1967). Przypomina o tym $\mathrm{Ka}$ techizm Kościoła katolickiego (2009), że sprawując sakrament pokuty, kapłan wypełnia posługę Dobrego Pasterza; jest znakiem i narzędziem miłosiernej miłości Boga względem grzesznika (KKK). Sam sakrament pokuty jest sakramentem przebaczenia, działania łaski i spotkania z Ojcem, który uzdrawia i razem z Eucharystią prowadzi wiernych drogą do świętości (Jan Paweł II 2004).

W niniejszym artykule omówiono obowiązki i kompetencje kapłana, przedstawiając najpierw wymagania co do sakramentu pokuty, a następnie ich realizację poprzez relację spowiednika z samym penitentem, a także ukazano znaczenie tychże kompetencji w sprawowaniu posługi sakramentalnej pośród ludzi młodych, z uwzględnieniem ich oczekiwań i problemów.

\section{Obowiązki i kompetencje kapłana jako szafarza sakramentu pokuty i pojednania}

Zasadnicze elementy pokuty sakramentalnej określono podczas Soboru Trydenckiego w 1551 roku, gdzie stwierdzono, że należy zwrócić uwagę na wyznanie grzechów przed uprawnionym szafarzem, którego prastarym zwyczajem nazywamy spowiednikiem (Jan Paweł II, n. 29). Następne etapy tegoż wyznania to: okazanie skruchy i postanowienie poprawy oraz - co najważniejsze - otrzymanie rozgrzeszenia udzielonego przez szafarza sakramentu, na mocy którego penitent uzyskuje odpuszczenie wszystkich grzechów po- 
pełnionych po chrzcie. Skutkuje to także równoczesnym pojednaniem z Kościołem, który został zraniony przez grzech (Ciccola i Targoński 2003, s. 31). Sakrament spowiedzi polega na wyznaniu grzechów, czyli confessio. To wyznanie jest istotnym elementem zaistnienia samego sakramentu. Możemy go także nazywać sakramentem przebaczenia, ponieważ poprzez rozgrzeszenie kapłana Bóg udziela penitentowi przebaczenia i pokoju (por. 2 Kor 5,20), a także sakramentem pojednania, ponieważ udziela spowiadającemu się miłości Boga, która niesie ze sobą pojednanie (Kongregacja ds. Duchowieństwa 2012, s. 149). Chrystus przebaczający grzechy to objawienie miłosiernej miłości Boga, który przygarnia człowieka, nie stawiając mu żadnych warunków (Szentmartoni 1995, s. 85). Kodeks prawa kanonicznego odnośnie do szafarza stanowi, że spowiednik musi być kapłanem oraz - oprócz święceń kapłańskich - musi mieć uprawnienia do sprawowania sakramentu pokuty i pojednania oraz mieć kanoniczną władzę rozgrzeszania, aby spowiedź była ważna. Takie upoważnienie kapłan dostaje na mocy samego prawa albo zostaje mu nadane poprzez kompetentną władzę (KPK 2008, kan. 965-966). W sakramencie pokuty i pojednania, działającym ex opere operato, jest udzielane w sposób szczególny Boże przebaczenie, gdyż Jego miłość, niezależnie od przymiotów i zasług szafarza, spływa na wszystkich, którzy z tego sakramentu korzystają (Jan Paweł II 2012, s. 247).

Posługa ta jest kompletna wtedy, gdy sprawujący ją kapłan wypełnia trzy obowiązki: słucha spowiedzi, ma władzę rozgrzeszania, nakładając jednocześnie pokutę, oraz motywuje penitenta do naprawienia wyrządzonych krzywd. Spowiednik musi być gotowy do wysłuchania spowiedzi, ilekroć jest o to proszony (Wons 2012, s. 282-283). Dyspozycyjność kapłana polega właśnie na tym, aby być gotowym do udzielania tego sakramentu. To on powinien oczekiwać na penitenta, a nie odwrotnie (Długosz 2012, s. 164). Sprawowanie sakramentu pokuty wymaga od kapłana poświęcenia czasu i troski, a także stawiania go ponad inne zajęcia i prace. Posługa kapłańska w sakramencie przebaczenia może i powinna przyczyniać się do odnowienia człowieka, umocnienia go i skierowania na drogę, która wiedzie do świętości. W istocie sam sakrament jest znakiem i narzędziem wewnętrznego zjednoczenia z Bogiem oraz służy jedności całego rodzaju ludu Bożego. Funkcje (munera) kapłańskie są ściśle ze sobą złączone dobrem wiernych (Kongregacja ds. Duchowieństwa 2012, s. 147). W sakramencie pojednania kapłan nie pełni roli tylko i wyłącznie upominającego, ale przede wszystkim powinien ukazywać prawdziwą miłość Bożą otwartą na pozytywne nauczanie. Sakrament pokuty ipso facto udziela zatem łaski i pomnaża ją, jednocześnie przynosząc dar pokoju. Ten dar przychodzi przez posługę szafarza dzięki zbawczej interwencji Boga, przywraca niewinność i daje zmartwychwstanie duszy (Zagrodzki 2012, s. 177). 
Ów dar pokoju otrzymany od samego Chrystusa w dzień zmartwychwstania (por. J 20, 22-23) potwierdza wprowadzona w 1973 roku formuła rozgrzeszenia, która jest używana do dzisiaj: „Bóg Ojciec miłosierdzia, który pojednał świat ze sobą przez śmierć i zmartwychwstanie Syna swojego i zesłał Ducha Świętego na odpuszczenie grzechów, niech ci udzieli przebaczenia i pokoju przez posługę Kościoła" (Miralles 2009, s. 104). Formuła ta zakłada trzy elementy: szafarza, który na mocy prawa i odpowiedniej władzy odpuszcza grzechy, osobę grzesznika oskarżającego się z powodu swoich grzechów oraz grzechy, które są przedmiotem oskarżenia (Płatek 1996, s. 155). Formuła ta, którą szafarz sakramentu powinien wypowiedzieć w całości, wskazuje, że pojednanie człowieka z Bogiem i Kościołem dokonuje się przez miłosierną miłość Boga do człowieka (KKK 1484). W tejże formule odnajdujemy głęboką prawdę o przebaczającym Ojcu, którego cieszy widok powracającego dziecka (por. Łk 15,1-3. 11-32). Kapłan prosi Boga, aby ten odpuścił grzechy i wspomógł swoją łaską. W powyższej formule rozgrzeszenia, którą wypowiada kapłan, odnajdujemy głęboki aspekt paschalny, zanurzenie w męce, śmierci i zmartwychwstaniu Chrystusa, które wyrywa człowieka ze śmierci duchowej. Sakrament pokuty, odgrywający tak wielką rolę w życiu chrześcijanina, uobecnia odkupieńczą skuteczność paschalnego misterium Chrystusa (Benedykt XVI 2012, s. 124). Spowiedź jest sakramentalną przestrzenią, w której dostrzegamy działanie Boga. Pragnie On dać człowiekowi łaskę pokoju przez odpuszczenie grzechów płynącą z przebaczenia. Warto podkreślić także wymiar eklezjalny absolucji, ponieważ cały Kościół, za pośrednictwem kapłana, modlitwami, miłością i wstawiennictwem modli się za grzesznika (Płatek 1996, s. 143-144). Udzielenie rozgrzeszenia wzmacnia cnotę i pomaga w niej wytrwać człowiekowi nawracającemu się. Upomnienie Chrystusa skierowane do grzesznej kobiety: „Idź i więcej nie grzesz” (J 5,14), uświadamia każdemu kapłanowi, że pole jego działania jest ograniczone wobec pola działania Boga odpuszczającego grzechy tym wszystkim, którzy szczerze za nie żałują (Sobolewski 2007, s. 43-46). Chrystusowe przebaczenie grzechów jest również wezwaniem do duchowej przemiany swojego życia, ponieważ Pan nie przyszedł, aby potępiać, ale przebaczać i zbawić ludzi (por. J 3,17). Poprzez sakrament pokuty Bóg patrzy na grzesznika inaczej: zagląda w jego wnętrze z wysokości krzyża i przebacza, uwalniając go od grzechu i śmierci wiecznej. Pojednanie z Bogiem jest nierozdzielne z pojednaniem z braćmi.

Kluczem do właściwego rozumienia pojednania jest ciągła pamięć o istniejącej harmonii duszy i ciała, którą zakłóca nieustannie grzech. Zauważa już to św. Paweł, pisząc do Rzymian: „Nie czynię bowiem dobra, którego chcę, ale zło, którego nie chcę. [...] Toczę zaś walkę z prawem mojego umysłu i pobija mnie w niewolę pod prawo grzechu mieszkającego w moich członkach" (Rz 7,19.23). Spowiedź sakramentalna jest działaniem Chrystusa, który czyni 
człowieka dobrym, czyli pozwala mu w pełni uczestniczyć w życiu Bożym. Aby się to dokonało, potrzebna jest jednak wiara uobecniona w zaufaniu skierowanym do Boga, który uzdrawia i przygarnia. Jak naucza bł. ks. Michał Sopoćko, w spowiedzi świętej nie tylko są odpuszczane grzechy, lecz także udzielana jest łaska uchronienia przed nimi oraz łaska wspomagająca w dążeniu do dobra (Ciereszko 2012, s. 344). Spowiednik musi przede wszystkim pomóc człowiekowi w odkryciu samej istoty sakramentu pokuty i pojednania, czyli pozwolić zranionemu przez grzech dotknąć cudownego miłosierdzia Bożego, które najpełniej ukazało się w ofierze Krzyża. Powinien zwrócić uwagę penitenta na przebaczającego Boga, który poprzez absolutio uzdrawia i wszystko czyni nowe. Jest zatem konieczne, aby w ocenie grzechu kapłan kierował się nauczaniem Kościoła, a nie swoimi opiniami, swoje zaś oceny wyrażał w sposób jasny i konkretny, z miłością i odwagą (Długosz 2012, s. 167).

Sprawowanie sakramentu pokuty i pojednania, zarówno ze strony kapłana, jak i penitenta, nie jest żadną ,psychiczną torturą”, jak niektórzy twierdzą, ale sięganiem do wnętrza człowieka i uzdrawianiem najgłębszych oraz najsłabszych jego aspektów. Jak zauważył papież Franciszek, konfesjonał nie powinien być salą tortur, ale miejscem miłosierdzia Pana, zachęcającego nas do czynienia możliwego dobra (Franciszek 2013, s. 45-46). Celem samego sakramentu nie jest upokorzenie człowieka przed kapłanem, ale duchowe pojednanie z Bogiem i posługa miłości, które w ostateczności prowadzą do zmartwychwstania duchowego. Najskuteczniejszym środkiem ku temu jest powrót do przyjaźni z Bogiem i Kościołem.

\section{Obowiązki i kompetencje kapłana w stosunku do penitenta}

Posługa miłosierdzia pełniona przez kapłana z wielką dyspozycyjnością przyczynia się do pogłębienia w penitencie miłości Boga do niego, prowadzi go do odbudowania poczucia grzechu, który przeszkadza miłości, bo jest jej wypaczeniem. Zwracając się do Boga Miłości, trzeba uznać swój grzech i skierować swą myśl ku Bogu, który jest większy od naszego serca (por. $1 \mathrm{~J} 3,20$ ). Kapłan zasiadający w konfesjonale jest nie tylko urzędowym szafarzem świętych sakramentów, lecz także w pełni realizuje swoje człowieczeństwo. Poprzez to powierzona mu zostaje intymność ludzka i duchowa penitenta, która złączona z jego intymnością tworzy pełny obraz kapłana jako spowiednika. Szczególnym wyrazem doskonałości i dobrego podejścia kapłana do spowiadającego się penitenta jest wrażliwość spowiednika, jego wyrozumiałość oraz wiedza, którą powinien zgłębiać nieustannie, aby rozwijać w sobie wciąż nowe zainteresowanie sprawami i życiem penitenta. Ponadto kapłańską postawę wobec grzesznika powinno kształtować nieustannie otwarcie rozumiane na 
sposób Chrystusa, który stając się człowiekiem, ujawnił to w swojej postawie wobec drugiego człowieka (Augustyn 2012, s. 253-255). W dobrym rozumieniu penitenta może pomóc modlitwa kapłana zanoszona za spowiadającego się i pokuta, którą podejmie kapłan za nawrócenie grzesznika. Powinno to wynikać nie tylko z obowiązku, lecz przede wszystkim z głębokiego spojrzenia na penitenta jak na człowieka potrzebującego Bożej miłości i miłosierdzia. Spowiednik nie jest panem ani urzędnikiem, ale jest sługą pojednania i miłosierdzia Bożego. Kiedy kapłan rozezna sytuację trudną i bolesną, w której mogą znaleźć się niektórzy penitenci, może ich podnieść na duchu, umocnić słowem Bożym i zapewnić o swojej modlitwie. Źródłem tego jest pogłębiona przez kapłana znajomość Ewangelii, dzięki której może on bardziej nauczyć się kochać i rozumieć drugiego człowieka. Umocnienie słowami Pisma Świętego będzie świadectwem wiary oraz zapewni człowieka spowiadającego się o poważnym podejściu kapłana do jego osoby i jego grzechów. Ta empatia ze strony kapłana jest potrzebna do duchowego wzrostu penitenta, ale stanowi także narzędzie, dzięki któremu sam spowiednik doznaje uświęcenia. Empatyczne podejście jest dobre, lecz musi być kontrolowane, aby nie przerodziło się w pobłażanie dla grzechu (także swojego). Nie należy jednak być nadmiernie pobłażliwym, ani też nadmiernie surowym, aby dać „wytchnienie” swojemu sumieniu (Dziewiecki 2012, s. 299-300).

Dobry spowiednik potrafi uszanować wolność penitenta. Stara się zrozumieć nie tylko to, co dotyczy spowiedzi, lecz także życia duchowego człowieka, całego jego rozwoju i braków w tej dziedzinie. Spowiednik nie jest panem, lecz sługą Bożego przebaczenia. Sprawując zatem ten sakrament, kapłan musi nieustannie pamiętać, że „wypełnia posługę Dobrego Pasterza, który szuka zagubionej owcy; posługę dobrego Samarytanina, który opatruje rany; Ojca, który czeka na syna marnotrawnego i przyjmuje go, gdy powraca; sprawiedliwego Sędziego, który nie ma względu na osobę, i którego sąd jest sprawiedliwy, a równocześnie miłosierny" (Kongregacja ds. Duchowieństwa 2011, s. 150-151). Z jednej strony, kapłan występuje jako reprezentant Chrystusa, Nauczyciela Prawdy, z drugiej - w roli sędziego, który orzeka sprawiedliwie i zgodnie z prawdą. Spowiednik nieustannie musi pamiętać, że wolność penitenta i świadomość jego sumienia są podstawą owocnie przeżytego sakramentu pokuty i pojednania. Szafarz sakramentu pokuty jest tylko urzędowym świadkiem przebaczenia grzechów synowi marnotrawnemu przez kochającego Ojca (por. Łk 15,11-32). Każdy przejaw surowości może być sygnałem dla spowiednika, że nie szanuje wolności penitenta lub ją ogranicza, przez co może zniechęcić go do ponownego korzystania z tegoż sakramentu. Należy zawsze pamiętać o tym, że wolność wewnętrzna jest centrum spotkania człowieka z Bogiem, oraz o tym, że najważniejszym miejscem uczenia się człowieka jest osobista przyjaźń z Jezusem (Augustyn 2012, s. 256). 
Z poszanowaniem wolności wiąże się także możliwość ułatwienia wyznania grzechów penitentowi, który przy pomocy szafarza ma możliwość poznania siebie w świetle wiary, nawracając się i odpowiadając na miłość Bożą. Jest to niewątpliwie bardzo istotne ze względu na ważność i integralność spowiedzi, zwłaszcza w przypadku grzechów ciężkich. Spowiedzi nie można traktować jako prywatnego spotkania człowieka z człowiekiem, ale raczej jako spotkanie wspólnoty Kościoła, której kapłan jest reprezentantem, z Bogiem. Dlatego spowiednik nie powinien ingerować w te obszary życia penitenta, które nie mają koniecznego odniesienia do poprawy jego życia moralnego i duchowego. Wykazując się wielką delikatnością i taktem, musi uszanować uczucia penitenta, nawet wtedy, gdy nie zgadzają się z zasadami sprawiedliwości i miłości (Witek 1979, s. 99).

Kapłan kompetentnie wypełniający swoją posługę w konfesjonale rozumienie człowieka zawsze opiera na Bożym zamyśle, przez co z łatwością przychodzi mu traktowanie go z należytym szacunkiem i obdarzanie tą miłością, jaką Chrystus umiłował Kościół. W duchu tej miłości każdy spowiednik ma świadomość tego, że za każdym grzechem człowieka kryje się ludzka słabość i dramat odłączenia od Boga i Jego miłości. Spowiednik zatem nie powinien patrzeć na penitenta przez pryzmat grzechu, ale dostrzegać w nim osobę z problemami i trudnościami, a także z tajemnicą, którą kryje w sobie jako osoba. Grzesznik „odsłania” swoje wnętrze, a za grzechy otrzymuje odpowiednią pokutę sakramentalną. Pokuta powinna polegać na widzialnym procesie nawrócenia i otwarcia się na Słowo Boże.

Kapłan, przyjmujący grzesznika pokutującego i doprowadzający go do światła prawdy, pełni zadanie ojcowskie, objawiając ludziom serce Ojca i nosząc obraz Chrystusa Dobrego Pasterza (Kongregacja ds. Kultu Bożego 1973, nr 10c). W powyższym zdaniu Ordo Penitentiae przypomina o ojcowskiej roli kapłana w sakramencie spowiedzi. W tej posłudze kapłan ma stosować zasadę św. Ambrożego i stawać się vicarius amoris Christi, przez co ma pomóc penitentowi dopełnić jego obowiązków, umożliwić odbycie dobrej spowiedzi i wyznanie grzechów. Pomagając penitentowi w jego wzrastaniu w wierze poprzez sakrament pokuty i pojednania, kapłan powinien kierować go na drogę Ewangelii, aby w jej świetle rozpatrywał swoje życie i postępowanie. W tym pouczeniu słowa zachęty i umocnienia powinny przeważać nad hardą mową (Ciccola i Targoński 2003, s. 55). Okazanie zainteresowania penitentem jest bardzo ważne. Nie może on mieć wrażenia, że kapłan nie pozwala mu się wypowiedzieć lub w pośpiechu przerywa jego wypowiedź. Kluczem do dobrego wypełniania posługi konfesjonału jest życzliwość i autentyczna miłość do człowieka, którego grzech oddala od Boga, a który potrzebuje słów nadziei i otwarcia na łaskę Bożą. Zrozumienie okazane człowiekowi uwikłanemu w grzech to duży krok do tego, aby z tych, którzy są nam powierzeni, nikogo 
nie stracić (por. J 6,39), ale przyjść im z realną pomocą. Im więcej kapłan ma w sobie miłości Bożej, tym więcej powinien jej okazać penitentowi, gdyż oddziałuje na niego całym swoim życiem, które odzwierciedla jego osobowość (Witek 1979, s. 97-104, 281).

W doświadczeniu konfesjonału kapłan powinien ufać spowiadającemu się (tak jak Paweł zaufał Chrystusowi i wyznał wiarę w Niego), mniej oceniać, a więcej miłować. Postawa dialogu jest tą postawą, która pozwoli na prowadzenie penitenta. Spowiednik nie ograniczy się tylko do nauki i pokuty, ale pozwoli nawiązać relację opartą na wzajemnym szacunku i miłości. Dialog nie polega tylko na dawaniu gotowych rad i recept, ale przede wszystkim na kontakcie interpersonalnym z penitentem, poszanowaniu jego wolności i zostawieniu mu wyboru (Kroplewski 2012, s. 264-265).

\section{Realizacja posługi spowiednika w kontekście życia ludzi młodych}

Młodość to szczególny okres w życiu człowieka, w którym nastolatek odkrywa po kolei piękno świata, piękno swojego ciała i swoją cielesność, uczy się kochać i być kochanym, wkracza powoli w dorosłość. Dlatego czas ten jest ważny nie tylko z fizycznego punktu widzenia, dotyczącego prawidłowego rozwoju, lecz także duchowego. Młody człowiek powinien mieć dobrze ukształtowaną moralność i życie duchowe, aby mógł prawidłowo funkcjonować we wspólnocie Kościoła. Okres zmian, którym podlega młody człowiek, może się przyczynić zarówno do jego pozytywnego, jak i negatywnego wzrostu. Zmiany te często wynikają z czynników rozwojowych, wychowawczych i środowiskowych, a więc dotyczą szerokiego zakresu życia psychicznego, psychoseksualnego i społecznego. Dlatego kapłan powinien znać proces rozwojowy młodzieży, zwracać szczególną uwagę na jej potrzeby i możliwości (Płatek 2001). Bardzo często na te czynniki oddziałuje także sytuacja rodzinna czy społeczna młodego człowieka. Konsekwencją tego jest brak autorytetu w domu i szukanie go poza nim, co nierzadko zupełnie osłabia funkcjonowanie człowieka w normalnym społeczeństwie. Te wszystkie czynniki nie mogą być obce spowiednikowi, ponieważ do niego - szukając pomocy - przychodzą młodzi ludzie poranieni przez życie. Spowiednik, poprzez przeanalizowanie tych czynników, może okazać im niezbędną pomoc w ich trudnościach.

Problemem ludzi młodych nie jest oderwanie od rzeczywistości, w jakiej żyją, ale samotność wynikająca z braku właściwego wzorca rodzinnego, moralnego i społecznego. Człowiek młody potrzebuje uznania, zwłaszcza swoich najbliższych. Brak zauważenia, ciągłe upomnienia i negatywne emocje przyczyniają się do niskiej samooceny, kompleksów, a w skrajnych wypadkach 
do autodestrukcji. Częstym problemem ludzi młodych jest niemożność poradzenia sobie z samotnością, bólem, a także z miłością ze strony innych, serdecznością, której nigdy nie doznali. To prowadzi do bardzo powierzchownej religijności opartej na uczuciach, doznaniach czy wzruszeniach. W tej pobożności nie ma stałości i zakorzenienia, jest za to działanie pod wpływem chwili czy emocji. Brakuje zmierzenia się z rzeczywistością, która bywa zupełnie odmienna od wyidealizowanego obrazu chrześcijaństwa. To z kolei jest bezpośrednią przyczyną odrzucenia religijności, pobożności, Kościoła, a w konsekwencji - samego Boga.

Z funkcjonowaniem ludzi młodych w społeczeństwie wiąże się także sfera psychoseksualna. To w tym czasie mamy do czynienia $\mathrm{z}$ największym zainteresowaniem płcią przeciwną, większą emocjonalnością i uczuciowością, a także z problemami masturbacji, aborcji, antykoncepcji czy wierności drugiemu człowiekowi.

Z badań ks. Wojciecha Sabika, przeprowadzonych wśród licealistów archidiecezji przemyskiej w 2007 roku, których celem było ustalenie wyzwań stojących przed spowiednikami w Polce, zwłaszcza pośród młodzieży, wynika, że młodzież oczekuje, iż spotka w konfesjonale kapłana, który będzie przychylnie nastawiony do penitenta oraz będzie próbował zrozumieć jego problemy, dylematy, wysłucha go i spróbuje pomóc mu zmagać się z trudnościami młodego wieku. Młodzi penitenci oczekują od spowiednika: szczerej rozmowy i odpowiedzi na nurtujące ich pytania, pomoc w rozwiązywaniu problemów związanych z wiekiem, dobrego wsparcia duchowego i psychologicznego oraz indywidualnego podejścia (Sabik 2013).

Spowiednik musi dysponować czasem i nauczyć się obdarowywać nim innych. Dyspozycja w tej materii jest bardzo wskazana. Kiedy penitent widzi kapłana w konfesjonale, to zakłada, że jest on gotów go wysłuchać. Czasami spotyka się z nietaktownym potraktowaniem ze strony spowiednika. Wówczas młody człowiek nie będzie chciał entuzjastycznie podejść do kolejnej spowiedzi, bojąc się powtórnego odrzucenia, lub poczuje się potraktowany od niechcenia. To może powodować odkładanie spowiedzi z dnia na dzień, a ostatecznie w nieskończoność. Brak czasu, na który cierpi dzisiaj połowa ludzkości, szybkie tempo wszystkich prac, to czynniki mogące mieć negatywny wpływ także na spowiedź. Kapłan, który bezustannie pogania penitenta lub przerywa jego wypowiedź, przypuszczalnie ostatni raz spowiada tego człowieka. Prawdopodobnie taki penitent już do niego nie powróci lub całkowicie zaniecha sakramentu spowiedzi. Tymczasem, kiedy spowiednik zachowa się jak jego przyjaciel, który ma czas na to, żeby go wysłuchać, poda kilka przyjacielskich uwag i podpowie, jak pewne sprawy uporządkować, może być pewny nie tylko tego, że penitent będzie go darzył serdecznością i wdzięcznością, lecz także tego, że nastąpi pogłębienie jego życia duchowego. Dla 
młodego człowieka bardzo ważne jest to, że zostanie wysłuchany, a nie tylko pouczony. Młodzież szuka dialogu w konfesjonale, choć często boi się pytać, bo nie wie, jaka będzie reakcja spowiednika. Człowiek młody, mimo że czasami sobie tego nie uświadamia, szuka zrozumienia, także w konfesjonale. Stąd bardzo ważną cechą kapłana jest budowanie swojej osobowości na tyle, aby wywrzeć dodatni wpływ na penitenta (Płatek 1996, s. 438). Każde przyznanie się do grzechu wywołuje uczucie wstydu nie tylko przed samym sobą, lecz także przed kapłanem, a przede wszystkim przed Bogiem. Dlatego spowiednik powinien umieć zrozumieć młodego człowieka, jego przeżycia, obawy i umacniać jego nadzieje oraz dobre postanowienia. Kapłan w sakramencie pokuty jest ojcem duchowym dla każdego człowieka. Tego ojcostwa potrzebują zwłaszcza ludzie młodzi, którzy stoją na początku swojego życia. Kapłan ma im pomóc odkrywać oblicze miłosiernego Ojca, ukierunkowywać ich patrzenie na Boga i dawać ciągle kolejne szanse, aby zawsze mogli wracać (por. Łk 15,11-18).

Spowiednik, który interesuje się życiem młodego człowieka, będzie wiedział, że stawiając wymagania w konfesjonale, powinien podać mu kilka propozycji rozwiązań, w jaki sposób ma je zastosować w życiu. Takie mobilizowanie do działania doda młodemu penitentowi odwagi, aby zastosować się do zaleceń spowiednika. Wybór zawsze należy do niego, dlatego wszelkie wymuszanie będzie tutaj bardzo niewskazane. Dlatego rozsądny spowiednik, któremu zależy na odpowiedzialnym podejściu do życia przez penitenta, będzie oddziaływał na jego wybory życiowe, ale nie będzie podejmował decyzji za niego samego (Płatek 1996, s. 434). Aby przemiana człowieka się dokonała, potrzebny jest czas, w którym młody człowiek musi poukładać swoje życia i wdrożyć w nie rady spowiednika. Warto zapewnić penitenta, że wielkie rzeczy dokonują się w wielkim trudzie, jednocześnie pamiętając o tym, że czasami, dając dużo, można bardzo zranić, a dając mało, można serce bardzo rozradować. Dlatego warto młodemu człowiekowi stawiać wymagania, jednak trzeba robić to w odpowiedni sposób, dostosowując je do wieku i możliwości penitenta. Wymagania stawiane z miłością i kierowane dobrem duchowym penitenta zawsze przyniosą dobre owoce. Spowiednik powinien dostrzec wysiłki, które włożył penitent w poprawę swoich zachowań i umacniać go w nich, a także mobilizować do dalszych działań. Wśród wskazań spowiednika mogą zdarzyć się takie obszary, których penitent nie będzie rozumiał.

To, co powinno charakteryzować dobrego spowiednika, to przede wszystkim kompetencja teologiczna, czyli wiedza, zwłaszcza z zakresu teologii moralnej i duchowości. Nie powinno mu także zabraknąć odwagi do podejmowania trudnych tematów i udzielania odpowiedzi na niełatwe i krępujące pytania. Nie wystarczy jednak tylko elokwencja. Potrzeba również, aby spowiednik troszczył się o swoje wnętrze, to znaczy ciągle się rozwijał i umac- 
niał swoją wiarę. Taki kapłan wzbudza nie tylko zaufanie, lecz także zyskuje szacunek młodych ludzi. Ma być mistrzem w sprawach duchowych i ludzkich. Jeśli spowiednik poważnie traktuje swoje obowiązki wynikające z wykonywanej posługi sakramentalnej, to powinien kształtować w sobie postawę bezgranicznego zaufania, zgodnie z oczekiwaniami i potrzebami młodych ludzi. Tylko zaufany spowiednik może wskazać i tym samym zbudować w penitencie właściwą postawę, którą charakteryzować będzie dojrzałość. „Z ludźmi młodymi można dokonać wielkich dzieł, jeżeli tylko zdobędzie się zaufanie, da się dobry przykład i umiejętnie, sercem i rozumem, poprowadzi" (Smoleń 2012, s. 391).

Spowiednik potrzebuje także dobrej znajomości psychiki, zarówno żeńskiej, jak i męskiej. Stąd też ważna jest wiedza spowiednika w tej materii. Inaczej odczuwa i realizuje swoją religijność dziewczyna, a w inny sposób chłopak. U dziewcząt bardzo ważną rolę odgrywają uczucia, stąd też spowiednik powinien budzić w nich poczucie własnej godności, a także bronić przed złudzeniami i iluzjami. U chłopców natomiast dominuje tzw. ideał honoru, z czego może się zrodzić przesadny krytycyzm. Męska psychika charakteryzuje się rzeczowością i prostolinijnością, dlatego do chłopców przemawia argumentacja czysto logiczna i zwięzła. Te cechy są także polem szukania dialogu ze spowiednikiem w czasie sakramentu pokuty, którego nie powinno się bagatelizować (Płatek 1996, s. 435-437). To wszystko ma prowadzić młodego człowieka do prawdziwego kontaktu z Jezusem Chrystusem, który przyszedł zbawić człowieka. Dlatego jest ważne, aby spowiednik umiał wytworzyć między penitentem a Bogiem, działającym w sakramencie pokuty, taką więź, która będzie wypływać z czystej i prawdziwej miłości mającej źródło w Nim i pomoże młodemu człowiekowi rozwijać się duchowo.

\section{Zakończenie}

Sakrament pokuty i pojednania to wielki dar dla Kościoła. W nim człowiek otrzymuje pojednanie z Bogiem i z Kościołem, w nim doznaje oczyszczenia i formuje swoją osobowość chrześcijanina, doskonaląc rozwój swoich nadprzyrodzonych cnót i życia duchowego. Pomocą dla niego na tej drodze jest spowiednik.

Kompetencje i obowiązki spowiednika są bardzo zróżnicowane i składa się na nie wiele czynników. Mimo tej różnorodności, są ze sobą scalone. Ważne są zarówno obowiązki, które stoją przed spowiednikiem, jak i jego kompetencje do tego, aby właściwie wykonywać powierzoną mu posługę. Celem posługi spowiednika nie jest jego własne zadowolenie czy samorealizacja, ale odkrycie przed penitentem drogi, którą ma on podążać do królestwa niebieskiego. 
Analizując kwestie związane ze spowiedzią ludzi młodych, można wysnuć wniosek, że nie są oni negatywnie nastawieni do sakramentu spowiedzi i często podchodzą do niego bardzo poważnie. Jedyny mur, na który nierzadko natrafiają, to sam spowiednik. Dlatego kapłan, który sam jest penitentem, musi nieustannie dbać o swój własny stan i rozwój duchowy w sposób bardziej wyczulony i dogłębny niż inny chrześcijanin.

\section{STRESZCZENIE}

Sakrament pokuty i pojednania to wielki dar dla Kościoła. W nim człowiek otrzymuje pojednanie z Bogiem i z Kościołem, w nim doznaje oczyszczenia i formuje swoją osobowość chrześcijanina, doskonaląc rozwój swoich nadprzyrodzonych cnót i życia duchowego. Pomocą dla niego na tej drodze jest spowiednik. W duchu swojego powołania pełni on posługę Dobrego Pasterza na wzór Chrystusa, o czym uczy nas Katechizm Kościola katolickiego (KKK 1465). Zadaniem, jakie spoczywa na spowiedniku, jest troska o lud mu powierzony i postawa sługi, który pochyla się nad nędzą drugiego człowieka. Posługa miłosierdzia, jaką podejmuje spowiednik, zawsze powinna mieć na celu dobro bliźniego. Dlatego wszystkie wskazówki udzielane penitentowi powinny być tak dostosowane, aby w jak największym stopniu odpowiadały jego wiekowi i stanowi. W niniejszym artykule omówiono obowiązki i kompetencje kapłana, a także wymagania co do sakramentu pokuty. Następnie ukazano znaczenie tychże kompetencji w realizacji posługi sakramentalnej pośród ludzi młodych z uwzględnieniem ich oczekiwań i problemów.

Słowa kluczowe: sakrament pokuty i pojednania; kompetencje spowiednika; młodzież

\section{THE FUNCTION OF THE CONFESSOR AND THE IMPLEMENTATION OF THE SACRAMENTAL SERVICE TOWARDS THE SPIRITUAL NEEDS OF YOUNG PEOPLE}

\section{SUMMARY}

The sacrament of penance and reconciliation is a great gift for the Church. In it, man receives reconciliation with God and the Church, is purified and forms his Christian personality, brings to perfection his/her development of supernatural virtues and spiritual life. The confessor helps a person on this way. In the spirit of his calling he serves as the Good Shepherd like Christ, as the Catechism of the Catholic Church teaches us (CCC 1465). The task that rests on the confessor is to take care of the people entrusted to him and to do this in the attitude of the servant who bends over the 
misery of man. The ministry of mercy, which the confessor performs, should always aim at the good of his fellow-creatures. Therefore, all directions given to the penitent should be adjusted so that they correspond as far as possible to his age and state. The article discusses the duties and competences of the priest. First, it presents the requirements for the sacrament, then their implementation in relation to the penitent, and finally shows the importance of these competences in the implementation of the sacramental service among young people, taking into consideration their expectations and problems.

Keywords: sacrament of penance and reconciliation; confessor's competences; youth

\section{BIBLIOGRAFIA}

Augustyn J. (red.) (2012): Sztuka spowiadania. Poradnik. Kraków.

Benedykt XVI (2007): Przemówienie do spowiedników papieskich bazylik i członków Penitencjarii Apostolskiej. „L'Osservatore Romano” 5: $2007 \mathrm{nr} 43$.

Ciccola G., Targoński F. (2003): Poradnik spowiednika. Kraków.

Ciereszko H. (2012): Ksiądz Michat Sopoćko wzorem spowiednika. W: J. Augustyn (red.), Sztuka spowiadania. Poradnik s. 335-345. Kraków.

Długosz A. (2012): Doniostość, trud i piękno sakramentu pojednania. W: J. Augustyn (red.), Sztuka spowiadania. Poradnik s. 161-170. Kraków.

Dziewiecki M. (2012): Kompetencje spowiednika w rozumieniu penitenta. W: J. Augustyn (red.), Sztuka spowiadania. Poradnik s. 299-305. Kraków,

Franciszek (2013): Adhortacja Evangelii gaudium. Częstochowa.

Jan Paweł II (2012): Posługa kapłańska w sakramencie pojednania. W: J. Augustyn (red.), Sztuka spowiadania. Poradnik s. 247-251. Kraków.

Jan Paweł II (2004): Sakrament przebaczenia uzdrawia i uświęca. Przemówienie do uczestników kursu zorganizowanego przez Penitencjarię Apostolską w dniu 27 marca 2004 r. „L'Osservatore Romano" 6: 2004 s. 27-28.

Katechizm Kościoła katolickiego [KKK]. (2009). Poznań.

Kodeks prawa kanonicznego. (2008). Poznan.

Kongregacja ds. Duchowieństwa (2012): Postuga pokuty i pojednania w perspektywie świętości chrześcijańskiej. W: J. Augustyn (red.), Sztuka spowiadania. Poradnik s. 143-160. Kraków.

Kongregacja ds. Kultu Bożego (1973): Ordo Penitentiae.

Kroplewski Z. (2012): Kultura dialogowania w konfesjonale. W: J. Augustyn (red.), Sztuka spowiadania. Poradnik s. 263-270. Kraków.

Miralles A. (2009): Teologia Liturgica dei sacramenti. 4. Penitenza, 89-157. http://www.liturgiaetsacramenta.info/texts/tl_penitenza.pdf.

Pismo Święte Starego i Nowego Testamentu (Biblia Tysiaclecia). (2002). Poznań.

Płatek J.S. (1996): Sprawowanie sakramentu pokuty i pojednania. Częstochowa.

Płatek J.S. (2001): Sprawowanie sakramentu pokuty i pojednania. Częstochowa.

Sabik W. (2013): Podstawowe wyzwania dla spowiedników w Polsce. http://sfd.kuria.lublin.pl/ index.php?Option=com_content\&view=article\&id=967:podstawowe- $\quad$ wyzwania-dla-spowiednikw-w-polsce-ks-w-sabik\&catid $=36$ :formacjakapaska\& Itemid $=65 . h t m l$.

Smoleń J. (2012): Jak dzisiaj spowiadać ludzi młodych? W: J. Augustyn (red.), Sztuka spowiadania. Poradnik s. 385-391. Kraków.

Sobolewski Z. (2007): Vademecum dobrej spowiedzi. Warszawa. 
Sobór Watykański II (1967): Dekret o posłudze i życiu kapłanów Presbyteriorum ordinis. W: Sobór Watykański II, Konstytucje, dekrety, deklaracje s. 754-812. Poznań.

Szentmartoni M. (1995): Psychologia pastoralna. Kraków.

Witek S. (1979): Sakrament pojednania. Podręcznik dla duszpasterzy. Poznań-Warszawa.

Wons K. (2012): Jak spotykać się z penitentem? Od przyjęcia prawdy o grzechu do przyjęcia przebaczenia i pokoju. W: J. Augustyn (red.), Sztuka spowiadania. Poradnik s. 271-288. Kraków.

Zagrodzki W. (2012): Spowiednik u źródet kryzysu spowiedzi? W: J. Augustyn (red.), Sztuka spowiadania. Poradnik s. 171-181. Kraków.

BARTlOMIEJ Dolata: ks. doktorant, słuchacz Studiów Podyplomowych Teologii na Wydziale Teologicznym Uniwersytetu im. Adama Mickiewicza w Poznaniu; e-mail: dolabart16@gmail.com. 